\title{
A Summing Up
}

\section{Leadership and Constituencies}

in the 1911 Revolution

\author{
ERNEST P. YOUNG \\ University of Michigan
}

Asked to comment briefly on the preceding exchange of views, I quickly decided that the role of referee would be both presumptuous and unnecessary. Esherick's points are clearly stated, and the authors are quite able to speak for themselves. The reader can best judge the differences by resorting to the books and articles at issue. One virtue of this sort of exchange is the stimulus it gives to reading (or rereading) with fresh questions in mind the important literature on the subject.

Instead of attempting reconciliations, I shall make a few points of my own on two general issues around which a number of remarks by both Esherick and his respondents cluster.

The question of the role in the late Qing and the 1911 Revolution of the republican revolutionary movement remains with us. I have long been sympathetic with the effort to escape from an interpretation of the Revolution preoccupied with Sun Yat-sen's activities. I believe that the view from the localities 
and provinces is an important corrective to narratives focused on the leading personalities in the Tongmenghui.

However, in our reaction to the cult of Sun or the "orthodox school," we might let the pendulum swing farther than is reasonable. While denying control or internal cohesion to the leading revolutionary party, we need not simultaneously deny it its ideological, propagandistic, and organizational contributions. An important determinant of the form of the 1911 Revolution (although decentralized, it was remarkably uniform, including republican commitments and military governments in the provinces) was the groundwork laid by the republican revolutionary movement. For all their factionalism and tenuousness of control, the Tongmenghui group were leading contenders for national power in 1912 and 1913 . That they failed to achieve it is a measure of their limitations as a political force. But it does not prove the force to have been negligible.

Once the question was, why did the famous leaders of the Revolution not administer the successor state? Perhaps the interpretive problem is now reversed: given the weakness of the national revolutionary organization at the time of the Revolution and its marginality to so many of the main events, how does one explain its considerable influence after the Revolution and the anxiety with which its challenge was regarded by its chief enemies, for example, Yuan Shi-kai and Liang Qi-chao?

As with the investigation of the revolutionary period from the perspective of local and provincial history, the pursuit of this question will likely lead to consideration of the social content of the Revolution. One of the strengths of Harold Schiffrin's study of Sun Yat-sen is its attention to the social context of Sun's ideas and to the relationship between changes in those ideas and Sun's changing alliances with different, potentially anti-Qing, social groups. Generally speaking, literature published in America and England lags far behind that of China or Japan in examining the social basis and consequences of the 1911 Revolution. Now that the examination has begun here, however, we may expect a lengthy debate, more likely to 
be terminated by exhaustion than consensus. This prospect in no way diminishes the importance of the effort; on the contrary, it bespeaks the centrality of the problem for an understanding of modern Chinese history.

Let us consider the question of the augmentation of gentry power through the Revolution, a matter touched upon by Esherick and several respondents. Esherick and Rhoads assert the fact of increased gentry power and, at least implicitly, its importance for understanding the Revolution and its aftermath. Gasster objects to the proposition, both because it belittles the Revolution and the changes it represented and because it neglects the long-term trend of gentry decline. For Elvin, the "long-term" comes within months of the Revolution: gentry power was "in many respects" at its nemesis in 1912-1914." Both Gasster's and Elvin's objections seem related to a preference for a finer segmentation within social categories and for focusing on new social or occupational groups.

Although Elvin seems to view the 1911 Revolution itself as at least partly a reaction against modernization, he and Gasster emphasize the "economic, intellectual, and social transformation" (Elvin) or the "vast social revolution" (Gasster) inaugurated between the 1890s and the May Fourth Movement. While old hierarchies and privileges (that is, the gentry position) were being destroyed, a new, modern order (represented by the new occupations) was taking their place. Gentry domination of the Revolution has no place here; or the Revolution itself must be separated out as a somewhat anti-modern, but short-lived, episode in a forward, modernizing movement.

It is not easy to escape from the feeling that to assert gentry domination or usurpation of the Revolution is to rob a major event of significance. Indeed, those who assert it, like Esherick and Rhoads, allow a basis for a degree of forward movement through the identification of a separated and relatively progressive segment of the gentry: a "new gentry" (Rhoads) or an "urban reformist elite" (Esherick in his dissertation). By hypothesizing a split in the elite, attributing nationalistic 
motivations to one part of it (the national and provincial elite), and denying them to the other (the local elite), Esherick in his essay here lays the basis for a politically progressive result accompanying a socially regressive revolution.

Although eschewing the word "gentry" for the period of the Revolution, Rankin seems to be critical of emphasis on a split elite. She objects to distinctions based on motivation. This point raises the question: can the provincial and reformist gentry be characterized as less self-interested and more idealistic than the local gentry? If the answer is "no," then the politically progressive aspect of the 1911 Revolution would seem to have lost its social grounding. In a second objection to the hypothesis of a split elite, Rankin writes that the social changes accompanying the emergence of reformist leaders "did not normally involve a strong break with traditional patterns, nor did they weaken the hold of pervasive native-place and clan ties." The suggestion is that the elite had not yet socially split in 1911 .

This chain of discourse could, of course, be broken at any point with objections or embellishments. But I should like to observe two conceptual issues that seem to me relevant here. The first is the distinction between social segmentation and social movement. New activities and enterprises developed in China, especially from the 1890 s, that seem from our presentday perspective to be quite distinct by virtue of their "nontraditional" aspect. Hence we are inclined to assign large social significance to their emergence and too easily jump to the conclusion that political change must be grounded in the new social segments. But in the period of the 1911 Revolution, when people joined together outside the government to affect politics and thereby formed movements, the definition of the recruiting pool was more often the old social categories than the new occupations. And it understandably would be so, since only in the New Army, in the new schools, and among overseas Chinese would the numbers and resources of the new groups be sufficient. When it comes to the intersection between society and politics in this period, we should note the new groups. But 
we cannot neglect the central importance of categories like peasant, merchant, and gentry, no matter how many segments can be delineated within each.

True, so much that was new was happening in politics from the 1890 s onwards. Was this activity compatible with a largely inherited class structure? I think the matter can best be understood in terms of a dynamic model of class behavior. That a social class (with all its segments) behaved and defined its interests in a certain way in the 1870 s does not necessarily mean that both behavior and definition of interests cannot have changed considerably by 1910 , especially in view of changing educational and communication structures. Old social groups undertook new activities, influenced by new ideas and new perceptions of class interest. Idealism and self-interest converged.

Similarly, it is by no means clear that the large social chasm between city and countryside that marks later decades had grown by 1911 much beyond what it had long been. When Esherick cites David Buck on the widening rural-urban gap, the remark refers in the original to the 1930s. Processes that were leading toward such a gap may perhaps have been set in motion around the time of the 1911 Revolution or even earlier. But I believe they were not sufficiently mature in 1911 to have been major influences on the Revolution.

Even if a politically significant split in the social elite cannot be defined, however, one need not relegate the 1911 Revolution to the category of nonevent. The limitations of the Revolution and the fragility of the new order may have arisen from the predominantly elitist character of the social base. On the other hand, a heightened political cohesiveness within the gentry elite, despite its social segmentation, may help explain the historic achievement of the overthrow of the ancient imperial order.

\section{NOTE}

1. My reading of some of the sources Elvin cites for this view has left me with a different conclusion. The social disorder in the countryside during 1912 and 1913 
was a symptom of the consolidation of gentry power rather than a sign of its demise. Mass armies, mobilized during the Revolution, turned (or returned) partly to banditry when demobilized, and were thereby transformed from social threats to familiar nuisances. As Rankin observes here, the effort to deal with this social turbulence and protest distracted the elite from "innovation," but the effort was socially reinforcing for the gentry. Meanwhile, widespread gentry absorption of local governmental powers added to gentry social weight. 